\title{
PEMBERIAN KOTORAN LARVA KUMBANG TANDUK (Oryctes rhinoceros) UNTUK MENINGKATKAN PERTUMBUHAN BIBIT KELAPA SAWIT (Elaeis guineensis Jacq) DI PEMBIBITAN UTAMA
}

\author{
Desi Rahmiaty Pulungan, Wardati, Hafiz Fauzana
}

Fakultas Pertanian Universitas Riau

e-mail:desirahmiaty@gmail.com

\begin{abstract}
Feces of rhinoceros beetles larvae (kolarhino) is an organic fertilizer that is obtained from defecation of rhinoceros beetles larvae that using empty palm fruit bunches as the feed. This research aims to look at the effect of giving kolarhino and get the best dose for the growth of oil palm seedlings (Elaeis guineensis Jacq) in the main nursery. The researched was carried out at Faculty of Agricultural experiment station, University of Riau from August to November 2016. This research using a completely randomized design which consist of 6 treatments and 4 replications level: 0, 25, 50, 75, 100 and $125 \mathrm{~g} /$ plant. Giving kolarhino on oil palm seedlings showed a significant in the increase of number of leaves, the increase of diameter stump, root volume and dry weight of seedlings but showed not significant to plant height increment and shoot root ratio. Giving kolarhino at a dose of $75 \mathrm{~g} /$ plant up to $125 \mathrm{~g} /$ plant increase of number of leaves, the increase of diameter stump and root volume, while the dose of $100 \mathrm{~g} / \mathrm{plant}$ and 125 $\mathrm{g} /$ plant increase of dry weight of oil palm seedlings.
\end{abstract}

Keywords: kolarhino, organic fertilizer and oil palm seedlings.

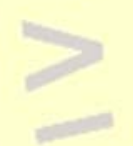

ABSTRAK

Kotoran larva kumbang tanduk (kolarhino) merupakan pupuk organik yg diperoleh dari hasil defekasi larva kumbang tanduk yang memakan tandan kosong kelapa sawit (TKKS). Penelitian ini bertujuan untuk melihat pengaruh pemberian kolarhino dan mendapatkan dosis terbaik untuk pertumbuhan bibit kelapa sawit (Elaeis guineensis Jacq) di pembibitan utama. Penelitian ini dilakukan di Fakultas Pertanian Universitas Riau pada bulan Agustus sampai November 2016 menggunakan rancangan acak lengkap yang terdiri dari 6 perlakuan dan 4 ulangan yaitu 0 g/tanaman; 25, 50, 75, 100 dan $125 \mathrm{~g} / \operatorname{tanaman}$. Pemberian kolarhino pada bibit kelapa sawit menunjukkan peningkatan nyata pada pertambahan jumlah daun, diameter bonggol, volume akar dan berat kering bibit kelapa sawit tetapi tidak menunjukkan peningkatan nyata terhadap pertambahan tinggi tanaman dan rasio tajuk akar. Pemberian kolarhino pada dosis $75 \mathrm{~g} /$ tanaman sampai $125 \mathrm{~g} /$ tanaman meningkatkan pertambahan jumlah daun, pertambahan diameter bonggol dan volume akar, sedangkan dosis $100 \mathrm{~g} /$ tanaman sampai $125 \mathrm{~g} /$ tanaman meningkatkan berat kering bibit kelapa sawit.

Kata kunci: kolarhino, pupuk organik dan bibit kelapa sawit.

\section{1}

\section{PENDAHULUAN}

Kelapa sawit (Elaeis guineensis Jacq) merupakan komoditas perkebunan unggulan di Indonesia dan penyumbang devisa terbesar dari sektor non migas selain karet dan kopi
(Puspita et al, 2012). Direktorat Jenderal Perkebunan (2016) menyatakan luas areal kelapa sawit Riau pada tahun 2015 adalah 2.400 .876 ha. 
Asmono (2016) menyatakan pada tahun 2015 hingga 2016 kondisi harga CPO masih lemah, sehingga bisa menjadi peluang bagi pelaku usaha untuk mempertimbangkan peremajaan bagi kebun-kebun yang sudah memasuki umur di atas 25 tahun. Menurut data Dinas Perkebunan Provinsi Riau (2014) luas areal yang memasuki tahap peremajaan pada tahun 2014 mencapai 10.247 ha.

Besarnya luas areal kebun kelapa sawit yang akan diremajakan tentu membutuhkan bibit berkualitas dalam jumlah yang banyak. Bibit merupakan produk pertama dari suatu proses pengadaan tanaman. Bibit kelapa sawit yang digunakan harus memiliki kualitas yang baik secara fisik dan genetik, karena akan menentukan produksi kelapa sawit di lapangan, dengan demikian pembibitan harus dikelola dengan baik.

Pengelolaan yang dilakukan untuk mendapatkan bibit berkualitas salah satunya dengan melakukan pemupukan. Pemupukan harus dilakukan secara tepat, baik itu jenis, dosis, cara, waktu dan metodenya. Salah satu jenis pupuk yang baik untuk digunakan adalah pupuk organik, sebab pupuk organik memiliki kemampuan meningkatkan kesuburan tanah dan memperbaiki sifat fisik, kimia dan biologi tanah.

Rinsema (1993) menyatakan bahwa pupuk organik mampu memperbaiki struktur tanah. Penguraian bahan organik oleh organisme tanah menghasilkan produk yang bersifat sebagai perekat, yang mengikat partikel-partikel tanah. Pupuk organik juga mampu menaikkan daya serap tanah terhadap air, karena bahan organik mempunyai daya absorpsi yang besar terhadap air tanah.

Bahan organik mempunyai peranan penting sebagai bahan pemicu kesuburan tanah, baik secara langsung sebagai pamasok hara bagi organisme authotrof (tanaman) juga sebagai sumber energi bagi organisme heterotrof (fauna dan mikroorganisme tanah).
Meningkatnya aktivitas biologi tanah akan mendorong terjadinya perbaikan kesuburan tanah, baik kesuburan fisik, kimia maupun biologi tanah yang searah dengan kebutuhan tanaman (plant requirement) akan mampu memperbaiki pertumbuhan dan produksi tanaman (Subowo et al, 2002 dalam Sahputra et al, 2016). Bahan organik di dalam tanah merupakan sumber energi mikroba dan mikrofauna untuk menghasilkan senyawa organik, yang diperlukan dalam proses agregasi pertikel tanah membentuk struktur tanah. Pemberian pupuk kandang sebagai bahan organik akan mendorong pembentukan makro agregat dari pada mikro agregat tanah (Jian-bing et al, 2013).

Kotoran larva kumbang tanduk (kolarhino) merupakan salah satu pupuk organik yang diperoleh dari hasil defekasi larva kumbang tanduk (Oryctes rhinoceros) yang memakan limbah organik seperti tandan kosong kelapa sawit (TKKS). Susanto et al. (2011) menyatakan bahwa kumbang tanduk merupakan hama yang utama menyerang tanaman kelapa sawit di Indonesia, khususnya di areal peremajaan kelapa sawit. Hama ini menggerek pucuk kelapa sawit yang mengakibatkan terhambatnya pertumbuhan yang menurunkan produksi dan rusaknya titik tumbuh sehingga mematikan tanaman.

Masalah kumbang tanduk saat ini semakin bertambah dengan adanya aplikasi tandan kosong kelapa sawit pada gawang maupun pada sistem lubang tanam besar. Pada sistem lubang tanam besar bertujuan untuk memperbaiki struktur tanah yang pada akhirnya dapat meningkatkan produktifitas kelapa sawit. Menurut Susanto et al. (2010) TKKS yang diaplikasikan setelah membusuk akan menjadi tempat perkembangan kumbang tanduk dan dapat langsung menyerang tanaman muda hasil peremajaan.

TKKS adalah limbah yang mengandung bahan organik yang dapat diubah 
menjadi pupuk organik melalui pengomposan. TKKS merupakan sumber makanan sekaligus tempat perkembangbiakan yang baik bagi larva kumbang tanduk (PPKS, 2012). Aktivitas kumbang tanduk memakan TKKS yang setengah lapuk menghasilkan bahan organik dengan ukuran yang lebih kecil dan bisa dimanfaatkan sebagai pupuk. Rahman (2015) menyatakan bahwa kumbang tanduk memiliki kemampuan mendegradasi TKKS. Oleh sebab itu, untuk menurunkan resiko penambahan populasi kumbang tanduk yang berdampak buruk pada pertumbuhan kelapa sawit maka dilakukan inovasi untuk memanfaatkan larva kumbang tanduk sebagai pendegradasi bahan organik untuk membuat pupuk organik, sehingga kumbang tanduk tidak lagi dipandang hanya sebagai hama, tapi juga objek yang memiliki nilai guna dan ekonomi.

Hasil Penelitian Wardati dan Adiwirman (2016) menunjukkan bahwa kolarhino mengandung $25,71 \% \mathrm{C}, 1,50 \% \mathrm{~N}$, $8,69 \% \mathrm{P}, 0,31 \% \mathrm{~K}, 12,20 \mathrm{me} / 100 \mathrm{~g} \mathrm{Ca}, 4,47$ $\mathrm{me} / 100 \mathrm{~g} \mathrm{Mg}, 0,77 \mathrm{me} / 100 \mathrm{~g} \mathrm{Na}$, unsur mikro 1,08 ppm Fe dan 2,34 ppm Zn. Penelitian ini bertujuan untuk melihat pengaruh dan mendapatkan dosis terbaik dari pemberian kotoran larva kumbang tanduk (kolarhino) untuk meningkatkan pertumbuhan bibit kelapa sawit (Elaeis guineensis Jacq) di pembibitan utama.

\section{METODOLOGI PENELITIAN}

Percobaan Fakultas Pertanian Universitas Riau, Kampus Bina Widya Kelurahan Simpang Baru Km 12.5 Panam, Pekanbaru. Penelitian ini dilaksanakan dari bulan Agustus sampai November 2016.

Penelitian ini dilaksanakan secara eksperimen dengan menggunakan Rancangan Acak Lengkap (RAL) yang terdiri dari 6 perlakuan dan 4 ulangan sehingga diperoleh 24 unit percobaan. Adapun perlakuan kolarhino terdiri dari 6 dosis yaitu: $0,25,50,75,100$ dan $125 \mathrm{~g} /$ tanaman.

Pelaksanaan penelitian meliputi persiapan kolarhino, persiapan tempat penelitian, persiapan bibit tanaman, persiapan medium tanam, pemberian perlakuan kolarhino, pemindahan bibit, pemeliharaan seperti penyiraman, pemupukan dasar, penyiangan dan pengendalian hama dan penyakit serta analisis kimia kolarhino. Adapun parameter yang diamati yaitu pertambahan tinggi bibit, pertambahan jumlah daun, pertambahan diameter bonggol, volume akar bibit, berat kering bibit dan rasio tajuk akar.

\section{HASIL DAN PEMBAHASAN}

\section{Hasil}

Pertambahan Tinggi dan Jumlah daun (cm) Pemberian kolarhino dengan berbagai dosis tidak memberikan pengaruh nyata terhadap pertambahan tinggi bibit kelapa sawit, namun memberikan pengaruh nyata terhadap pertambahan jumlah daun bibit kelapa sawit. Pertambahan tinggi dan jumlah daun bibit kelapa sawit setelah diuji lanjut dengan DNMRT pada taraf 5\% disajikan pada Tabel 1.

Tabel 1. Pertambahan tinggi dan jumlah daun bibit kelapa sawit dengan pemberian berbagai dosis kolarhino.

\begin{tabular}{ccc}
\hline $\begin{array}{c}\text { Dosis } \\
\text { Kolarhino } \\
\text { g/tanaman }\end{array}$ & $\begin{array}{c}\text { Pertambahan } \\
\text { Tinggi } \\
(\mathrm{cm})\end{array}$ & $\begin{array}{c}\text { Pertambahan } \\
\text { Jumlah Daun } \\
\text { (helai) }\end{array}$ \\
\hline 125 & $7,29 \mathrm{a}$ & $5,63 \mathrm{a}$ \\
100 & $3,18 \mathrm{a}$ & $5,00 \mathrm{ab}$ \\
75 & $5,13 \mathrm{a}$ & $5,13 \mathrm{ab}$ \\
50 & $4,94 \mathrm{a}$ & $4,38 \mathrm{bc}$ \\
25 & $3,84 \mathrm{a}$ & $4,13 \mathrm{c}$ \\
0 & $4,04 \mathrm{a}$ & $3,88 \mathrm{c}$ \\
\hline
\end{tabular}

Angka-angka pada kolom yang diikuti huruf kecil yang tidak sama menunjukkan 
berbeda nyata menurut uji jarak berganda Duncan pada taraf $5 \%$, untuk pertambahan tinggi telah ditransformasi akar kuadrat $\sqrt{\mathrm{y}}$.

\section{Pertambahan Diameter Bonggol dan Volume Akar Bibit}

Pemberian kolarhino dengan berbagai dosis memberikan pengaruh nyata terhadap pertambahan diameter bonggol dan volume akar bibit kelapa sawit. Pertambahan diameter bonggol dan volume akar bibit kelapa sawit setelah diuji lanjut dengan DNMRT pada taraf 5\% disajikan pada Tabel 2 .

Tabel 2. Pertambahan diameter bonggol dan volume akar bibit kelapa sawit dengan pemberian berbagai dosis kolarhino.

\begin{tabular}{ccl}
\hline $\begin{array}{c}\text { Dosis } \\
\text { Kolarhino } \\
(\mathrm{g} / \text { tanaman })\end{array}$ & $\begin{array}{c}\text { Pertambahan } \\
\text { Diameter } \\
\text { Bonggol }(\mathrm{cm})\end{array}$ & $\begin{array}{c}\text { Volume } \\
\text { Akar Bibit } \\
(\mathrm{ml})\end{array}$ \\
\hline 125 & $1,82 \mathrm{a}$ & $23,75 \mathrm{ab}$ \\
100 & $1,85 \mathrm{a}$ & $26,25 \mathrm{a}$ \\
75 & $1,78 \mathrm{a}$ & $18,75 \mathrm{abc}$ \\
50 & $1,21 \mathrm{~b}$ & $11,25 \mathrm{c}$ \\
25 & $1,25 \mathrm{~b}$ & $13,75 \mathrm{bc}$ \\
0 & $1,12 \mathrm{~b}$ & $16,25 \mathrm{bc}$ \\
\hline
\end{tabular}

Angka-angka pada kolom yang diikuti huruf kecil yang tidak sama menunjukkan berbeda nyata menurut uji jarak berganda Duncan pada taraf $5 \%$.

\section{Berat Kering Bibit dan Rasio Tajuk Akar}

Pemberian kolarhino dengan berbagai dosis memberikan pengaruh nyata terhadap berat kering bibit kelapa sawit namun tidak memberikan pengaruh nyata terhadap rasio tajuk akar bibit kelapa sawit. Berat kering dan rasio tajuk akar bibit kelapa sawit setelah diuji lanjut dengan DNMRT pada taraf 5\% disajikan pada Tabel 3.
Tabel 3. Berat kering dan rasio tajuk akar bibit kelapa sawit dengan pemberian berbagai dosis kolarhino.

\begin{tabular}{cc}
\hline $\begin{array}{c}\text { Dosis Kolarhino } \\
(\mathrm{g} / \text { tanaman })\end{array}$ & $\begin{array}{c}\text { Berat Kering Bibit } \\
(\mathrm{g})\end{array}$ \\
\hline 125 & $12,33 \mathrm{ab}$ \\
100 & $15,33 \mathrm{a}$ \\
75 & $10,85 \mathrm{~b}$ \\
50 & $9,61 \mathrm{~b}$ \\
25 & $10,93 \mathrm{~b}$ \\
0 & $9,28 \mathrm{~b}$ \\
\hline
\end{tabular}

Angka-angka pada kolom yang diikuti huruf kecil yang tidak sama menunjukkan berbeda nyata menurut uji jarak berganda Duncan pada taraf $5 \%$.

\section{Pembahasan}

Pemberian kolarhino dengan berbagai dosis menunjukkan peningkatan nyata pada pertambahan jumlah daun, pertambahan diameter bonggol, volume akar dan berat kering bibit (Tabel 1, Tabel 2 dan Tabel 3), namun tidak menunjukkan peningkatan nyata pada pertambahan tinggi tanaman dan rasio tajuk akar (Tabel 1 dan Tabel 3).

Pertambahan tinggi bibit berkaitan dengan rasio tajuk akar. Pertambahan tinggi dan rasio tajuk akar bibit kelapa sawit dengan pemberian kolarhino dosis $125 \mathrm{~g} /$ tanaman cenderung lebih besar dibandingkan tanpa diberi kolarhino (Tabel 1 dan Tabel 3), yang berarti dengan pemberian kolarhino ke dalam tanah mampu meningkatkan pertambahan tinggi dan rasio tajuk akar meskipun tidak secara nyata.

Kolarhino sebagai bahan organik memiliki pengaruh yang lebih besar terhadap perbaikan sifat fisik tanah dibandingkan kemampuannya untuk menyediakan unsur hara. Menurut Winarso (2005) bahwa penambahan bahan organik ke dalam tanah lebih besar pengaruhnya terhadap perbaikan sifat fisik tanah sedangkan peranannya untuk meningkatkan unsur hara hanya sebagai 
penunjang. Munawar (2011) menyatakan bahwa peningkatan bahan organik secara tidak langsung dapat meningkatkan porositas tanah melalui aktivitas fauna tanah, sehingga memacu infiltrasi dan mengurangi aliran permukaan. Bahan organik dapat memperbaiki struktur tanah sehingga stabilitas agregat tanah tetap terjaga. Dengan demikian, kondisi fisik tanah akan menjadi lebih baik dan menjamin ketersediaan air yang cukup. Air sangat dibutuhkan untuk pertumbuhan tanaman yaitu untuk melarutkan unsur hara, membantu akar menyerap unsur hara dan membantu proses fotosintesis.

Kemampuan kolarhino untuk meningkatkan ketersediaan unsur hara dapat secara langsung dan tidak langsung. Pengaruh langsung terjadi saat bahan organik diberikan ke dalam tanah maka proses mineralisasi akan terjadi, dimana bahan organik akan menyediakan unsur hara dalam bentuk yang dapat dimanfaatkan oleh tanaman. Proses mineralisasi ini berlangsung cukup lama, unsur hara untuk diperlukan belum tersedia dalam jumlah yang cukup sehingga hal tersebut diduga menjadi penyebab pertambahan tinggi dan rasio tajuk akar bibit kelapa sawit tidak menunjukkan peningkatan secara nyata.

Pemberian kolarhino dosis 75 g/tanaman sampai $125 \mathrm{~g} /$ tanaman mampu meningkatkan pertambahan jumlah daun, pertambahan diameter bonggol dan volume akar bibit kelapa sawit (Tabel 1 dan Tabel 2). Pada volume akar bibit kelapa sawit, pemberian kolarhino dosis $100 \mathrm{~g} /$ tanaman meningkat secara tidak nyata dengan dosis 75 $\mathrm{g} /$ tanaman, $25 \mathrm{~g} /$ tanaman dan tanpa pemberian kolarhino. Hal tersebut terjadi diduga karena tanaman akan tumbuh optimal jika ketersediaan unsur hara yang dibutuhkan dalam kondisi yang cukup, tidak berlebih ataupun defisit. Graham (1975) dalam Agustina (1990) menyatakan bahwa status nutrisi tanaman yang mempengaruhi pertumbuhan dan hasil tanaman berada pada zona defisiensi (kekurangan), zona cukup atau zona keracunan (kelebihan).

Unsur hara yang dibutuhkan bibit kelapa sawit untuk memicu peningkatan pertumbuhannya antar lain unsur $\mathrm{N}, \mathrm{P}$ dan $\mathrm{K}$ serta unsur makro dan mikro. Unsur hara N, P dan $\mathrm{K}$ pada analisis komposisi kolarhino masing-masing yaitu $1,50 \%, 8,69 \%$ dan 0,31\%. Unsur N merupakan komponen utama pembentuk organ tanaman sehingga sangat berperan untuk meningkatkan pertumbuhan vegetatif (Agustina, 1990). Unsur P kolarhino tergolong tinggi, sehingga diduga ketersediaan $\mathrm{P}$ di dalam tanah juga tinggi, namun $\mathrm{P}$ bersifat tidak mobil di dalam tanah. Unsur P lebih aktif jika berada di dalam jaringan tanaman. Menurut Munawar (2011) unsur P digunakan sebagai komponen penyusun energi (ATP dan nukleoprotein lain), untuk sistem informasi genetik (DNA dan RNA), untuk membran sel (fosfolipid) dan fosfoprotein. Selain itu P aktif berperan dalam pembelahan dan pembesaran sel, sehingga pembentukan jaringan tanaman meningkat. sedangkan peranan unsur $\mathrm{K}$ menurut Pratiwa (2014) yaitu berperan dalam pembentukan pati, mengaktifkan enzim, mengatur pembukaan stomata dan membantu pembentukan protein dan karbohidrat serta membantu translokasi hasil fotosintesis.

Dengan adanya penambahan kolarhino maka ketersediaan unsur N, P dan K yang ada di dalam tanah bisa dimanfaatkan oleh tanaman, sebab kolarhino yang mengandung bahan organik mampu memperbaiki sifat fisik, kimia dan biologi tanah. Tanah yang memiliki sifat fisik yang baik, berarti memiliki porositas yang bagus dan susunan agregat yang mantab, sehingga mampu mengatur pasokan air secara langsung yang menjadikan air tersedia dalam jumlah yang cukup untuk tanaman dan secara tidak langsung akan meningkatkan ketersediaan unsur hara, karena air berfungsi 
sebagai pelarut unsur hara agar bisa diserap tanaman.

Berat kering kelapa sawit meningkat secara nyata dengan pemberian kolarhino dosis $100 \mathrm{~g} /$ tanaman sampai $125 \mathrm{~g} /$ tanaman dibandingkan dengan dosis 0 g/tanaman sampai $75 \mathrm{~g} /$ tanaman (Tabel 3). Hal ini berarti dengan dosis pemberian kolarhino yang lebih besar meningkatkan berat kering bibit yang lebih besar juga. Berat kering bibit kelapa sawit dengan pemberian kolarhino dosis 100 g/tanaman meningkat secara tidak nyata dengan pemberian kolarhino dosis 0 g/tanaman sampai $75 \mathrm{~g} /$ tanaman. Hal ini diduga terjadi karena berat kering bibit memberikan respon yang baik apabila ketersediaan unsur hara sudah cukup, sehingga jika dikurangi atau ditingkatkan tidak lagi menunjukkan peningkatan secara nyata.

Kolarhino sebagai bahan organik diduga mampu meningkatkan aktivitas organisme tanah. Aktivitas organisme tersebut dapat memperbaiki sifat fisik dan kimia tanah. Menurut Arisha dkk (2003) bahan organik berperan positif dalam memperbaiki porositas dan kemampuan tanah menahan air serta meningkatkan kapasitas tukar kation dan $\mathrm{pH}$ tanah. Selain itu pupuk organik juga berperan meningkatkan keberagaman mikroorganisme dalam tanah yang menghasilkan fitohormon untuk merangsang pertumbuhan tanaman serta membantu penyerapan hara. Stevenson (1982) menyatakan pengaruh positif dari penambahan bahan organik adalah pada pertumbuhan tanaman yang disebabkan oleh senyawa perangsang tumbuh seperti auxin dan vitamin yang dihasilkan dari aktivitas biologis oleh mikrorganisme tanah.

\section{KESIMPULAN}

Dari hasil penelitian dapat disimpulkan sebagai berikut :

1. Pemberian kolarhino pada bibit kelapa sawit menunjukkan peningkatan nyata pada pertambahan jumlah daun, diameter bonggol, volume akar dan berat kering bibit kelapa sawit tetapi tidak menunjukkan peningkatan nyata terhadap pertambahan tinggi tanaman dan rasio tajuk akar.

2. Pemberian kolarhino pada dosis 75 g/tanaman sampai 125 g/tanaman meningkatkan pertambahan jumlah daun, pertambahan diameter bonggol, dan volume akar bibit kelapa sawit, sedangkan dosis $100 \mathrm{~g} /$ tanaman sampai $125 \mathrm{~g} /$ tanaman meningkatkan berat kering bibit kelapa sawit.

\section{SARAN}

Berdasarkan hasil penelitian yang telah dilaksanakan, untuk mendapatkan pertumbuhan bibit yang baik disarankan melakukan pemupukan dengan memberikan kotoran larva kumbang tanduk pada dosis 75 g/tanaman.

\section{DAFTAR PUSTAKA}

Agustina, L. 1990. Dasar nutrisi tanaman. Rineka Cipta. Jakarta.

Arisha, H. M. E., Gad, A. A. dan Younes S. E. 2003. Response of some pepper cultivar to organic and mineral nitrogen fertilizer under sandy soil conditions.Jurnal Agriculture, volume 30: 1875-99.

Asmono, D. 2016. Menggantang industri benih sawit di 2016. www.bumn.go.id/ptpn5/berita/16804/ Menggantang.Industri.Benih.Sawit.di.2 016. Diakses pada tanggal 20 April 2016.

Dinas Perkebunan Provinsi Riau. 2014. Riau fokuskan peremajaan perkebunan dan tumpang sari. www.bisnis.com. Diakses pada tanggal 17 April 2016. 
Direktorat Jenderal Perkebunan. 2016. Statistik perkebunan Indonesia 20152017: Kelapa Sawit. Sekretariat Direktorat Jenderal Perkebunan. Jakarta.

Gardner, F. P., R. B. Pearce dan R. L. Mitchell. 1991. Fisiologi tanaman budidaya. Universitas Indonesia (UI) Press. Jakarta.

Jian-bing, Z., Y. Jin-song, Y. Rong-jiang, Y. Shi-peng, L. Fu-rong and H. Xiao-jing. 2013. The effects of farmyard manure and mulch on soil physical properties in a reclaimed coastal tidal flat saltaffected soil. Journal of Integrative Agriculture. Andvanced Online Publication, P: 14.

Munawar, A. 2011. Kesuburan tanah dan nutrisi tanaman. Penerbit IPB Press. Bogor.

Pratiwa, R. 2014. Peran unsur hara kalium (K) bagi tanaman. Balai Besar Pelatihan Pertanian (BBPP) Lembang. Bandung.

Pusat Penelitian kelapa sawit (PPKS). 2012. Layanan Prima Proteksi Tanaman. Pusat Penelitian Kelapa Sawit Medan, hlm. 1-55.

Puspita, F., Y. Elfina, R. Rustam, H. Laoh dan D. Salbiah. 2012. Pengelolaan hama dan penyakit tanaman kelapa sawit berkelanjutan. Hal 49-65. Dalam: Suwondo dan S.I. Saputra (Eds). 2012. Perkebunan kelapa sawit berkelanjutan untuk kesejahteraan masyarakat. UR Press. Pekanbaru.
Rahman, Y. 2015. Composting tandan kosong kelapa sawit (TKKS) dengan poa : pengaruh sirkulasi tumpukan TKKS. Skripsi Tidak dipublikasikan. Departemen Teknik Kimia Fakultas Teknik Universitas Sumatera Utara, Medan.

Rinsema, W.T. 1993. Petunjuk dan cara penggunaan pupuk. Bharata Karya Akdara. Jakarta.

Sahputra, R.,Wawan dan E. Anom. 2016. Pengaruh kedalaman muka air tanah dan bahan organik terhadap ketersediaan hara dan pertumbuhan tanaman kelapa sawit (Elaeis guineensis jacq) di lahan gambut. Jurnal Online Mahasiswa, Volume 3 (1): 1-15.

Stevenson, F.J. 1982. Humus chemistry: genesis, composition, reaction. A Willey Interscience Publication. New York.

Susanto, A., Purba, RY \& Prasetyo, AE. 2010. Hama dan penyakit kelapa sawit volume 1. PPKS Press. Medan.

Susanto, A, Sudharto dan A. E. Prasetyo. 2011. Informasi organisme pengganggu tanaman kumbang tanduk (Oryctes Rhinoceros Linn). Pusat Penelitian Kelapa Sawit. Medan.

Winarso, S. 2005. Kesuburan tanah: dasar kesehatan dan kualitas tanah. Penerbit Gava Media. Yogyakarta. 